\title{
Collective strategy for facing occupational risks of a nursing team*
}

\author{
Estratégia coletiva de enfrentamento dos riscos ocupacionais \\ de uma equipe de enfermagem \\ Estrategia colectiva de enfrentamiento de los riesgos ocupacionales \\ del equipo de enfermería
}

Marli Maria Loro' ${ }^{1}$ Regina Célia Gollner Zeitoune ${ }^{2}$

How to cite this article:

Loro MM, Zeitoune RCG. Collective strategy for facing occupational risks of a nursing team. Rev Esc Enferm USP. 2017;51:e03205. DOI: http://dx.doi. org/10.1590/S1980-220X2015027403205

\begin{abstract}
* Extracted from the thesis "Riscos ocupacionais no cenário do trabalho em enfermagem: proposta de prevenção pela convergência da pesquisa e prática educativa”, Escola Paulista de Enfermagem, Universidade Federal de São Paulo, 2014.

${ }^{1}$ Universidade Regional do Noroeste do Estado do Rio Grande do Sul, Departamento de Ciências da Vida, Ijuí, RS, Brazil.

${ }^{2}$ Universidade Federal do Rio de Janeiro, Departamento de Enfermagem de Saúde Pública, Rio de Janeiro, RJ, Brazil.
\end{abstract}

\begin{abstract}
Objective: To socialize an educational action through the process of group discussion and reflection, with the aim to increase the care of nursing workers in facing occupational risks. Method: A qualitative descriptive study using the Convergent Care Research modality with nursing staff working in an emergency department of a hospital in the northwest region of the state of Rio Grande do Sul, Brazil. Data collection was carried out through educational workshops and information was processed using content analysis, resulting in two thematic categories: A look at the knowledge and practices about occupational risks in nursing; and adherence to protective measures by the nursing team against occupational risks. Results: Twenty-four (24) workers participated in the study. When challenged to critically look at their actions, the subjects found that they relate the use of safety devices to situations in which they are aware of the patient's serological status. Conclusion: Subjects' interaction, involvement and co-responsibility in the health education process were determinant for their reflection on risky practices. They also had the potential to modify unsafe behaviors.
\end{abstract}

\section{DESCRIPTORS}

Nursing, Team; Occupational Risks; Occupational Health; Health Education. 


\section{INTRODUCTION}

Nursing workers are exposed to a diversity of occupational risks and workloads which have the potential to determine illness processes. This is due to the peculiarities of the work, as well as its organization and division, since they remain in this environment throughout the working day and for much of their productive life ${ }^{(1)}$.

Risks/hazards and procedures at work are related to the interaction of the worker with a diversity of substances and materials in inappropriate physical environments/spaces, enhanced by the fast pace of work, pressure from supervisors, long shifts, inappropriate use or even the non-use of Personal Protective Equipment (PPE) and the lack of collective protection measures ${ }^{(2)}$. These situations lead to physical and mental exhaustion, which can result in work accidents and worker illness ${ }^{(3)}$. Understanding where the work is performed as well as the factors correlated with the professional practice are fundamental, especially in the scope of professional nursing practice ${ }^{(4)}$.

From this point of view, working conditions in hospitals over time are considered inadequate due to the peculiarities of the environment and the activities developed there. These conditions potentially generate physical and emotional exhaustion, determining the morbidity profile of workers. In addition, they are considered unhealthy as they allow workers to be exposed to a diversity of risks/hazards ${ }^{(5)}$, as identified from the perspective of the Ministry of Labor as any physical, chemical, psychological, mechanical and especially biological (risks), inherent to hospital work. There are still some authors who work from the perspective of work duties - classified into physical, chemical, biological, mechanical, physiological and psychological - ensuing from a dynamic interaction with the worker's body, resulting in processes of exhaustion. In this sense, identifying situations of exposure enables implementing health intervention strategies and improve the quality of life at work ${ }^{(4)}$.

The nursing team deserves special attention with regard to their safety and well-being at work. In particular, nurses who work in hospital emergency services, as these units have greater complexity in care, and a greater flow of activities as well as users. Working in this sector is complex, since workers need to develop their activities with agility, speed and effectiveness, since time is of the essence for critical patient care.

In addition, working in specific sectors such as urgency and emergency can contribute to increased exposure to occupational risks/hazards, since working in this sector is characterized by immediate and effective care of victims of trauma or unforeseen illnesses. It is often a highly stressful and hazardous environment for the team.

The work process in this environment is dynamic, stimulating and heterogeneous, yet it can expose workers to the risks inherent in the work process. Recognizing and controlling them is a necessity ${ }^{(6)}$, and the professionals who work there must acquire a safe attitude towards such risks, including the development of a preventive culture.

Therefore, it is fundamental to understand and know the social and political context that involves workers' health, as well as broadening the search for understanding social transformations to resignify the reality experienced by these professionals. It is also important to understand how and where the health/disease process occurs, to identify the workers' needs and how the work process in this area occurs ${ }^{(7)}$.

Emphasizing permanent educational actions is necessary since they enable recognizing the situations causing danger and their repercussions to the worker's life through occupational hygienic actions. In this sense, actions toward workers' health education have been the object of contemporary concern with the objective of reducing accidents and absenteeism, and improving workers' quality of life and health. Also, because the Ministry of Health and Labor has a policy to stimulate permanent education as a way to instrumentalize health professionals. In this sense, (Brazilian) Regulatory Norm 32 of the Ministry of Labor aims to establish basic guidelines for implementing measures to protect the health and safety of health service workers, providing that actions to train workers are developed on a continuous basis ${ }^{(8)}$.

These actions should promote information and education in the service and health of the worker, and thus aggregate elements that qualify inappropriate conduct and behaviors. Predetermined habits due to deep-rooted work processes can be transformed as workers perceive themselves as subjects in the work process.

The educational dimension is configured as a tool for the prevention of intercurrences, which instigates reflection and instrumentalizes workers in the perspective of a more critical praxis, thus avoiding risk situations ${ }^{(9)}$. Such actions need to start early, stimulating a culture of prevention as the basis of knowledge. In this context, developing educational actions based on Convergent Care Research (CCR) had the purpose of stimulating a group of workers to reflect on risk practices in the nursing work routine, and to collectively find ways to overcome them. This is because the CCR has the character of provoking reflection and change in order to reach new healthy lifestyles.

It is important to emphasize that studies on occupational risks/hazards have been researched by different authors in different realities and contexts. However, what has been observed is that such studies focus on investigating occupational risks/hazards, seeking to understand professionals' knowledge about them, and to analyze the use/disuse/misuse of personal protective equipment by workers. Some have pointed out risk/hazard perceptions and recommendations for educational activities in their conclusions. However, no studies have been found in the national and international literature that go further with proposals for educational interventions, or which have developed them in the field of worker's health, constituting something challenging and innovative.

Faced with this reality and based on research data, the present study aimed to socialize an educational action through a group discussion and reflection process, with the purpose of increasing the care of nursing workers facing occupational risks/hazards. 


\section{METHOD}

This study corresponds to an extract of a doctoral thesis that used the Convergent Care Research (CCR) approach. This type of research seeks to discover realities, solve problems or even introduce innovations about a certain reality ${ }^{(10)}$. It requires subjects to actively participate, guide their development, maintain a close relationship with the social situation and aims to find solutions to specific problems, thus seeking to change a given reality. It involves a discussion of the practice, experience, everyday life, and the understanding of structures and institutions as a result of objective actions. Moreover, this research modality prioritizes the involvement between researcher and research subjects in order to assume a deepening condition of the intersubjective relationship, seeking to understand a certain reality reported by social actors in their own narrative ${ }^{(10)}$. Analyzing professional practices using the CCR method makes it possible to understand subjective aspects of the subjects involved in the process, and it implies that the researcher knows the context and the reality under study. Thus, the workers were approached through participant observation before the workshops were developed in order to uncover the work process and how the worker behaves when facing risk/hazard situations in their daily lives, and the educational intervention based on CCR was only conducted later.

Twenty-four workers from the nursing team who worked in the urgency and emergency unit of a hospital in the northwest of Rio Grande do Sul state participated. Inclusion criteria were: being part of the nursing team for at least six months, working in the urgency and emergency sector and being over 18 years old. Exclusion criteria were: being away from work, on a leave or on vacation during the research.

Data was produced from May to August 2013. It emerged from a semi-structured interview with closed questions for sociodemographically characterizing the participants and conducting four educational workshops regarding occupational risks/hazards and preventive measures. Discussions, reflections and testimonies were recorded with the consent of the participants, and then later transcribed and analyzed.

Research and assistance/care activities were conducted cyclically in the meetings, meaning that each situation revealed by the participants corresponded to care actions when necessary and vice versa, making it possible to establish a close relationship between the study and the care with workers health, and the care provided by the nursing team.

The project was approved by the Research Ethics Committee, under Opinion number 21438/2012. Participants' anonymity was guaranteed by naming them with the letters SP (Study Participant) and numbers 1 to 24 . Thematic Content Analysis techniques were applied to the data, and two thematic categories emerged, namely: knowledge and practices about occupational risks of nursing work and protective measures implemented by the nursing team.

\section{RESULTS}

The study included 24 workers, six nurses and 18 nursing technicians. Females and the age group between 20 and 39 years were predominant. Regarding marital status, $50 \%$ were single. As for nurses' education level, two had a postgraduate degree and four technicians attended higher education and had worked in nursing for 1 to 4 years, characterizing a young group. With regards to training on work safety, the nurses were unanimous in affirming that they had received it. Two nursing technicians reported not having received it. Among the nurses, two had another job on their inverse shift, and 33\% of the nursing technicians group worked in another hospital institution on inverse shifts.

\section{A LOOK AT THE KNOWLEDGE AND PRACTICES ABOUT OCCUPATIONAL RISKS/HAZARDS IN NURSING}

The institution under study developed educational actions periodically. Among the topics of focus were activities aimed at preserving the physical integrity of workers. From the perspective of not repeating actions already developed by the institution, an approach that instigated subjects to reflect about their work process and its implication on their health and physical integrity was considered. Thus, the approach was focused on values and the motivational phrase that preceded the workshops was "I have value". This resulted from the understanding that in order to achieve greater adhesion among the workers, the intervention proposal needed to motivate them through something that made them reflect on their importance and their practice in the group of workers at the institution. We noticed the need to stimulate a proactive action in facing occupational risks/hazards, regardless of the legal or formal obligation to use the safety devices.

This step was started by putting the motivational phrase on the wall of the sector before the first workshop to cause curiosity, and to the same extent reflection by the workers. The questions were: "What's this? This is beautiful! Very colorful! Why is this in our sector?" At the time they were told that it was part of the proposed activity to which they were being invited to participate. Seeing the phrase every day provoked a very positive reflection in the group, to the extent to which they expressed that "it touched them," according to their statements.

So I have value (SP12).

Someone cares about me (SP5).

They are saying I am worth it ... so I have value and it made me feel important (SP7).

Thus, group discussion during the educational activity arose from values, taking into account the safety of the nursing worker. The initial use of (group) dynamics to warm up the theme helped to create a relaxed and playful environment, and incited participation by those involved in the proposed themes in a way they felt free to give their opinion, to suggest or even to disagree, which favored participants' reflection and expression. In short, our goal was to create a space for exchange and sharing of knowledge and experiences. 
As a result, the group demonstrated participation in the process, expressing their points of view and suggesting intervention strategies for the problems raised. It is important to analyze and evaluate the intrinsic and extrinsic factors of the work environment, as well as to recover professional valorization, which may stimulate adherence to biosafety actions.

In dialogues the workers expressed improvisation, the feeling of invulnerability and even the banalization of risks, which demonstrated a naive awareness of the worker in facing the risks arising from their workloads. In this sense, the dialogue allowed them to understand that it is necessary to adopt a proactive attitude towards situations, and it is also important to instill a prevention culture that goes beyond the daily routine of their praxis.

Occupational risks/hazards are part of our day to day life, sometimes more, sometimes less, but risks are always part of our activities (SP18).

We see all kinds of pathologies here and you only know after the patient has been hospitalized. Because until the doctor does an image test, a blood test ... then, when the reports come ... the patient has tuberculosis, hepatitis (SP24).

Participants stated that they sometimes needed to be fully informed of the possibilities of exposure and its consequences in order to implement all safety measures. They stated that, at times, they related the use of certain safety devices to the suspicion of contagious pathologies.

When it is the SAMU (ambulance) that brings the patient with tuberculosis, they put the mask on the patient, then when we receive them you can see that they have a respiratory problem and everyone ends up putting on the mask. Because if they have something, then that's how we protect ourselves (SP14).

When SAMU (ambulance) arrives, because they warn us in cases of serious patients. The staff laughs at me, I put on that big mask (which covers the whole face), that green apron, I look like Batman, but I have to protect myself, there's no way (SP24).

Now that the seasonal flu has started... we have to protect ourselves more (SP6).

According to statements, some workers pointed out an important aspect that was related to the fact that they should be careful with all patients who access the service, and biosafety norms should be observed regardless of knowing serological status.

We said that when we are warned that such a patient is coming, we protect ourselves, but it is not only with these patients that we have to protect ourselves, there are those who do not know what they have (SP11).

We also have to worry about the patient coming in through the other door (...) we not only have to worry about the emergency door, but also with the front door (SP14).

We are not always given advance notice, we cannot generalize (SP17).

Reports showed that doing things the easiest way was still predominant, rather than doing them in the adequate and safe manner. It is important to note that on several occasions the discomfort of some participants in relation to the interviews was felt, as in the affirmation that care practices only occur the moment they discover or are informed of the patient's health conditions. After reflecting, they concluded that what they lacked was awareness of the hazards of activities, and needed to change the way they positioned themselves in facing the risks/hazards.

We talked and in our view we lack awareness about the risks/ hazards and we need a change in attitude to confront the risks/ hazards (SP22).

It's our lack of care. I believe that what should be emphasized is the employee's awareness in understanding the space in which they are working, in maintaining use of PPE (SP9).

We need to educate ourselves and protect ourselves with all patients (SP7).

In this sense, it is important to recognize situations that cause risk/danger, as well as to intervene through occupational hygiene actions.

\section{ADHERENCE TO PROTECTIVE MEASURES BY THE NURSING TEAM IN FACING OCCUPATIONAL RISKS/HAZARDS}

Among the many hospital workplaces, emergency care units essentially need to give effective returns to the service users. Participants in the workshops understood that working in this sector requires a differentiated position and a deeper knowledge of work dynamics, as well as the need for protection to preserve their health.

I did not know what he had, and this I think this is a flaw in our health system, because the patient should have a medical history with them, today they come here, then they go over there, and you never know... (SP24).

Care must be taken with everyone arriving at the door of the service (SP17).

Their understanding sometimes differed, but through dialogue they concluded that standard precautions are one of the most important preventive measures to avoid exposure, regardless whether they are aware of the patient's serological status.

After some socialization moments, the workers synthesized the shared understanding of the group; meaning that safety measures should be implemented with all patients regardless of the form, reason or clinical condition that determined their accessing the service, as evidenced by their speeches.

We have to worry about all the patients that we care for, and also those who come through the other door, we not only have to worry at the emergency door, but also at the reception door (SP11).

Out there, in the emergency room, there is some equipment available for you to use right then, but each one of us has received our own PPE (SP4).

From reflecting about their work process, they concluded that they put themselves in risky/hazardous situations on several occasions and acknowledged that the institution provided the necessary means for nursing practice to be carried out safely. They found that awareness and co-responsibility were still incipient in the group. 
The institution provides enough means for you to protect yourself. It's there and that's why I say it is up to you to understand the sector you work in, it's up to you when you use any material, to go and put them back. Because if everyone gets the stuff from there, you'll need it and there will be none left (SP9).

The discussions and reflections in the group made it possible to identify situations experienced and to reflect on risky behavior.

What matters is when I see that a patient is going to need aspiration, it's up to you to stop and start thinking: They need care, yes, but I need to protect myself. Of course it has happened that I'm attending patients and I wasn't wearing protective glasses, I go to puncture a patient without wearing gloves and only then I realize that I'm not wearing gloves (SP6).

By the time the doctor asks for and runs all the tests, you have already touched the patient (...) then they come and say: "Let's isolate them...". Then you are already in trouble, because you're not always wearing all the protective gear (SP24).

Then there is what we have already said, how are you going to put on an apron after you have already had contact with the patient and you find out that they need to be isolated? This needs to be thought of in advance (SP9).

I myself have carried out several procedures without wearing the proper equipment (SP7).

But even if nursing workers make use of the proper equipment for protection, accidents can still happen, a fact that cannot be a motivator for not using safety equipment. It has happened that the glove ripped and I had contact with blood and had to take the (AIDS) cocktail (SP2).

Even with all equipment, accidents can still happen. The other day a patient with AIDS in a psychotic outbreak arrived, we punctured him and he ripped the access out and, when he took it off, we were all wearing gloves, but he shook the access like this and blood flew all over those of us near the patient, on our faces, on our lab coats. The nurse even made a police report (SP14).

The accident with the bike boy who had trauma, there was a lot of blood and when we went to pull bim to one side, my glove tore. It happens that the protective measure is not so effective, it is something that happens there at that time (SP17).

Another aspect related to worker exposure situations may be related to the intense demand for activities, the short time to perform care, and in particular the unpredictability of situations; and if the worker does not have an broadened view of the care, they can put themselves at risk.

When a patient arrives in a car and the staff goes to see them, it is that rush to take the patient out of the car. It's not like that.... (SP11).

When the bell rings, everyone rushes to the door, and we are not always prepared and wearing all the protection gear (SP2).

\section{DISCUSSION}

Knowledge construction must be based on an interactive process in which subjects possessing different knowledge are articulated from common interests ${ }^{(11)}$. It is understood that when implementing educational strategies, they should enable a repositioning of knowledge and rethinking of practices, thus it is important they are jointly assumed. It is necessary to establish a horizontal dialogic communication where both subjects can share experiences ${ }^{(12)}$.

In this sense, participatory construction of knowledge is a methodological strategy that takes into account the daily experience of the individuals involved and aims to achieve greater power and intervention in social relations that interfere in the quality of their lives, insofar as the educational dimension is focused on nursing work ${ }^{(13)}$. Moreover, educational actions in which there is subject and manager involvement, and which is based on real problems in the workplace leads them to have independence and to take responsibility for their own learning and self-learning, which is an important result for occupational health education ${ }^{(14)}$.

Group adherence to the activity is fundamental ${ }^{(15)}$. For $\mathrm{CCR}$, research, assistance and participation are the basis of the methodology, and it is from the articulation of these that the unifying element emerges, known as convergence, which implies thinking and doing, thus articulating theory and practice with participation and promoting democracy to the process. Thus, the need for research to enable knowledge expansion is being created, and should therefore be tied to the field of practice ${ }^{(15)}$.

The paths that lead workers to expose themselves to risks/hazards are accounted for by a set of situations such as communication, interpersonal relationships, lack of awareness of risks/hazards, and above all behavior ${ }^{(16)}$. Thus, nursing workers coming into contact with different and diverse etiological agents is frequent. This implies that the team must be aware during their performance of tasks and be in compliance with the standard precautions with all patients, regardless of the diagnosis ${ }^{(17)}$. They must also be in compliance with (Brazilian) Legislative Standard 32, which proposes Occupational Health and Safety measures in Health Facilities, and it is mandatory for companies to reduce, minimize or even eliminate a scenario in which the worker is exposed to situations detrimental to their health and physical integrity ${ }^{(8)}$.

However, it has been identified that the nursing team in this study linked the use of protective measures to the patient's clinical condition, which put them at risk to exposure. The study revealed that a large share of work intercurrences could be avoided if safety parameters were followed as provided by legislation ${ }^{(4)}$. Thus, it is imperative that the team adopts the use of all protective barriers as a daily practice, regardless of information or knowledge of the patient's condition, considering that accidents can happen, especially in a unit marked by unpredictability.

Workers in healthcare facilities often experience inappropriate work situations, not considering them as dangerous, even if scientific evidence reveals the presence of various risk agents and workloads in their work environment ${ }^{(18)}$. Thus, the way workers interpret their reality is materialized in their attitudes, which must sometimes be modified; a fact 
that can only happen with continued educational actions throughout the entire professional path ${ }^{(19)}$.

In proposing to discuss the theme "occupational risks/ hazards", we arrive at the problem; the perception of risky/ hazardous situations until then being disregarded by many of the subjects. Thus, it is imperative that workers assume the status of subjects and prioritize their own health preservation $^{(20)}$. It was also evident that verbalizing and discussing exposing situations in the group's daily lives constitutes learning, since joint reflection about problematic situations enables knowledge reconstruction.

Acting in an emergency department implies that the nurse is at the front lines of the health service, so it is imperative to consider that all patients may represent a potential risk $^{(21)}$, in addition to seeking protection of their own health and physical integrity.

In this way, $\mathrm{PPE}$ is an indispensable instrument for preventing injuries. However, the professional's resistance to using it, or even its incorrect use, are barriers to preventing exposure $^{(16)}$. It is paramount that the worker assumes the responsibility of their safety as a necessity, and appropriates knowledge about their work process, as well as those that have potential to occur when safety standards and standard protective measures are not considered.

This study points out that knowledge about risks/hazards in the workplace does not always guarantee adherence to the use of protective measures ${ }^{(16)}$. To this extent, educational activities are primordial in the search for changes, since they stimulate constructing critical thinking and promote a rethinking of ethics and sciences, focusing on the individual's qualification. In this context, health professionals need to undergo continuous training processes ${ }^{(20)}$.

In addition, low adherence to using PPE is due to factors such as discomfort, inconvenience, carelessness, forgetfulness and lack of habit, and it may be exacerbated by poor infrastructure, organizational aspects of work, lack of knowledge due to a lack of permanent education, work overload, stress, physical fatigue or lack of time ${ }^{(16)}$. A study infers that an increase in the use of safety devices is strongly related to the perception that professionals have about the risks/hazards of their work ${ }^{(22)}$.

It should be noted that any risky situation should be considered important and serious. It is imperative to remember that even so, intercurrences occur given that the care provided is marked by developing fast, decisive and effective actions. This implies being aware that scientific evidence points to the reflexes of risk exposure and to the work procedures arising from nursing praxis ${ }^{(4)}$.

Thus, the worker needs to be prepared and encouraged to instill a preventive culture in their daily lives, as improvisation frequently occurs in healthcare service; it becomes routine, concretizing this culture ${ }^{(16)}$ Despite the preparation and experience in the unit under study, the participants verbalized difficulty in applying the acquired knowledge and maintaining it throughout their professional activities.

Considering the ways in which the nursing team deals with occupational risks/hazards makes it possible to list important elements of professional practice; and to the same extent group reflections enable important aspects being brought up that need to be overcome with a view to maintain the health and physical integrity of workers, and the quality of services provided.

\section{CONCLUSION}

With this study we have concluded that the CCR is an effective research method, as it allows for developing educational actions and at the same time it effectively involves the participants in the research process. We can affirm that the worker's perception about the risks/hazards of their work, work overload, improvisation and trivializing risks/ hazards are among the situations generating exposure to occupational risks/hazards. Thus, implementing educational practices based on involved values and holding individual's responsible results in intense participation of those involved, and institutes changes in their reality regarding preventive practices against occupational risks/hazards. Interactions, involvement and co-responsibility of the subjects in the process were determinant for their reflection on the risky/ hazardous practices they had experienced.

We identified that subjects accumulated experiences that influenced their positions in facing the risks/hazards arising from their workloads. Thus, an educational action that stimulates reflection, promotes autonomy and protective position of themselves and of others is necessary.

Awareness from acting on knowledge is what characterizes the transition from a spontaneous apprehensive sphere of reality to a critical sphere. Thus, implementing the CCR methodology had the potential to produce co-responsibility in the workers, to incorporate health promotion actions, and to prevent occupational illnesses and accidents in their work routine by enabling knowledge appropriation regarding the reality in which they are inserted.

\section{RESUMO}

Objetivo: Socializar uma ação educativa, por meio de um processo de discussão e reflexão em grupo, com vistas a ampliar o cuidado dos trabalhadores de enfermagem frente aos riscos ocupacionais. Método: Estudo qualitativo, descritivo na modalidade Pesquisa Convergente Assistencial, com trabalhadores da equipe de enfermagem que atuavam no pronto atendimento de um hospital da região noroeste do estado do Rio Grande do Sul. A coleta de dados foi realizada por meio de oficinas educativas, e o tratamento das informações, por análise de conteúdo, resultando em duas categorias temáticas: Um olhar direcionado a saberes e práticas sobre riscos ocupacionais na enfermagem e Adesão às medidas de proteção pela equipe de enfermagem frente aos riscos ocupacionais. Resultados: Integraram o estudo 24 trabalhadores. Ao serem desafiados a olhar criticamente sobre seu fazer, os sujeitos constataram que vinculam o uso dos dispositivos de segurança a situações em que conhecem o status sorológico do paciente. Conclusão: A interação, o envolvimento e a corresponsabilização dos sujeitos no processo de educação em saúde foram determinantes para a reflexão das práticas de risco, bem como tiveram potencial para modificar comportamentos inseguros. 
DESCRITORES

Equipe de Enfermagem; Riscos Ocupacionais; Saúde do Trabalhador; Educação em Saúde.

\section{RESUMEN}

Objetivo: Socializar una acción educativa a través de un proceso de discusión y reflexión grupal, con el fin de ampliar el cuidado de los trabajadores de enfermería en relación a los riesgos ocupacionales. Método: Estudio cualitativo, descriptivo en modalidad de Investigación Convergente Asistencial, con trabajadores del equipo de enfermería que actuaban en el servicio de urgencia de un hospital de la región noroeste del estado de Rio Grande del Sur. La recolección de datos se realizó a través de talleres educativos y el tratamiento de las informaciones por análisis de contenidos, lo que resultó en dos categorías temáticas: una mirada dirigida a los saberes y las prácticas relacionadas a riesgos ocupacionales y la adhesión a las medidas de protección por el equipo de enfermería para los riesgos ocupacionales. Resultados: El estudio incluyó 24 trabajadores a los que cuando se presentó el desafío de observar su críticamente sus acciones, constataron que relacionan el uso de los dispositivos de seguridad a las situaciones en que el status serológico de los pacientes es ya conocido. Conclusión: La interacción, el involucramiento y la corresponsabilidad de los sujetos en el proceso de educación en salud son determinantes para la reflexión sobre las practicas riesgosas y tienen potencial para modificar comportamientos inseguros

\section{DESCRIPTORES}

Grupo de Enfermería; Riesgos Laborales; Salud Laboral; Educación en Salud.

\section{REFERENCES}

1. Souza RT, Bica CG, Mondadori CS, Ranzi AD. Avaliação de acidentes de trabalho com materiais biológicos em médicos residentes, acadêmicos e estagiários de um Hospital-Escola de Porto Alegre. Rev Bras Educ Med [Internet]. 2012 [citado 2016 jun. 22];36(1):118-24. Disponível em: http://www.scielo.br/pdf/rbem/v36n1/a16v36n1

2. Berton F, Di Novil C. Occupational hazards of hospital personnel: assessment of a safe alternative to formaldehyde. J Occup Health. 2012;54(1):74-8

3. Karino ME, Felli VEA, Sarquis LMM, Santana LL, Silva SR, Teixeira RC. Cargas de trabalho e desgastes dos trabalhadores de enfermagem de um hospital-escola. Cienc Cuid Saude. 2015;14(2):1011-8.

4. Santos Junior AG, Santos FR, Furlan MCR, Araújo JC, Arantes MB, Barbosa TS. Norma regulamentadora 32 no Brasil: revisão integrativa de literatura. Rev Enferm Cent Oest Min. 2015;5(1):1528-34

5. Mininel VA, Felli VEA, Loisel P, Marziale MHP. Cross-cultural adaptation of the work disability diagnosis interview (WoDDI) for the Brazilian context. Rev Latino Am Enfermagem. 2012; 20(1):27-34.

6. Mori K, Tateishi S, Hiraoka K, Kubo T, Okazaki R, Suzuki K, et al. How occupational health can contribute in a disaster and what we should prepare for the future-lessons learned through support activities of a medical school at the Fukushima Daichi Nuclear Power Plant in Summer. J Occup Health. 2013;55(1):6-10.

7. Mendes JMR, Wunsch DS. Serviço Social e a saúde do trabalhador: uma dispersa demanda Serv Soc Soc. 2011;(107):461-81.

8. Brasil. Ministério do Trabalho. Normas Regulamentadoras: segurança e medicina do trabalho. São Paulo: Atlas; 2013.

9. Soares LG, Labronici ML, Maftum MA, Kirchhof AL. Risco biológico em trabalhadores de enfermagem: promovendo a reflexão e a prevenção. Cogitare Enferm. 2011;16(2):261-7.

10. Trentini M, Paim L. Pesquisa convergente-assistencial. $2^{\text {a }}$ ed. Florianópolis: Insular; 2004.

11. Acioli S, David HMSL, Faria MGA. O perfil de enfermeiros fluminenses da ESF segundo um programa de educação permanente à distância Rev Enferm UERJ. 2012; 20(n. esp1):591-5.

12. Brito CGN, Silva NC, Montenegro L. Metodologia de Paulo Freire no desenvolvimento da educação permanente do enfermeiro intensivista. Enferm Rev. 2012;16(3):317-26.

13. Valim, MD, Marziale MHP. Avaliação da exposição ocupacional a material biológico em serviços de saúde. Texto Contexto Enferm. 2011;20 (n.esp.):138-46.

14. Dehdashti A, Mehralizadeh S, Kashani MM. Incorporation of project-based learning into an occupational health course. J Occup Health. 2013;55(3):125-31.

15. Marziale MHP. Indicadores de la producción científica iberoamericana [editorial]. Rev Latino Am Enfermagem. 2011;19(4):1-2.

16. Neves HCC, Souza ACS, Medeiros M, Munari DB, Ribeiro LCM, Tipple AFV. Safety of nursing staff and determinants of adherence to personal protective equipment. Rev Latino Am Enfermagem. 2011;19(2):354-61.

17. Lima LM, Oliveira CC, Rodrigues KMR. Exposição ocupacional por material biológico no hospital Santa casa de Pelotas: 2004 a 2008. Esc Anna Nery. 2011;15(1):96-102.

18. Valente GSC, Nogueira JRM. The regulatory standard 32 and nursing care in the emergency service of a teaching hospital. J Nurs UFPE Online [Internet]. 2012 [cited 2016 June 22];6(9):2103-10. Available from: http://www.revista.ufpe.br/revistaenfermagem/index.php/ revista/article/view/2798

19. Lubenow JAM, Moura MEB. Representações sociais sobre as causas dos acidentes com materiais perfurocortantes por técnicos de enfermagem. Rev Rene. 2012; 13(5):1132-41.

20. Luz FR, Loro MM, Zeitoune RCG, Kolankiewicz ACB, Rosanelli CSP. Riscos ocupacionais de uma indústria calçadista sob a ótica dos trabalhadores. Rev Bras Enferm. 2013;66(1):67-73. 
21. Rieth GH, Loro, MM, Stumm EMF, Rosanelli CLSP, Kolankiewicz ACB, Gomes JS. Use of individual protection equipments by nursing in an hospital emergency unit. Rev Enferm UFPE Online [Internet]. 2014 [cited 2016 June 22];8(2):321-7. Available from: http://www.revista. ufpe.br/revistaenfermagem/index.php/revista/article/viewArticle/3381

22. Chagas MCS, Barbosa MCN, Behling A, Xavier, DM. Occupational risk in emergency room: use of personal protective equipment (ppe) by nursing professionais. Rev Enferm UFPE Online [Internet]. 2013 [cited 2016 June 22];7(2):337-44. Available from: http://www.revista. ufpe.br/revistaenfermagem/index.php/revista/article/view/3549 